\title{
AN EXPERIMENTAL STUDY ON DURABILITY OF HIGH STRENGTH SELF COMPACTING CONCRETE (HSSCC)
}

\author{
N. Venkat Rao', M. Rajasekhar ${ }^{2}$, Mohd Mujeebuddin ahmed ${ }^{3}$ \\ ${ }^{1}$ Associate Professor, ${ }^{2,3}$ Assistant Professor, Department of Civil Engineering, Vardhaman College Of Engineering, \\ Andhra Pradesh, India \\ venkatnimmagaddi@gmail.com, rajasekhar.rp26@gmail.com,mujeebvce@gmail.com
}

\begin{abstract}
The basic philosophy in the construction of every structure is it should perform its intended functions successfully through the expected and anticipated life time, irrespective of external exposure conditions. The ability of the concrete is to resist and withstand any environmental conditions that may result in early failure or severe damages and it is a major concern to the engineering professional. Out of all the deteriorating agents acid attack is one of the phenomena that plays a vital role in disintegrating concrete structures depending on the type and concentration of the acid. Certain acids are harmless. The present investigation focused on the effect of $\mathrm{H}_{2} \mathrm{So}_{4}$ and $\mathrm{HCL}$ on High Strength Self Compacting Concrete.
\end{abstract}

Keywords: Self Compacting Concrete, Durability, deterioration, Compressive strength, viscosity modifying agent, Workability

\section{INTRODUCTION}

If we go through the annals of concrete history it reveals that for a long time concrete was believed to be very durable material requiring a little or no maintenance to the large extent the assumption may be true except when it is exposed to highly aggressive environment. The impression that concrete is very durable material is being threatened because the structures constructed in highly polluted urban and industrial areas, aggressive marine environments, harmful sub soil water in coastal areas and many other hostile conditions are being deteriorated, hence the longevity of these structures is reduced. In the past, earlier to 1930 the strength of the concrete was only considered in the concrete mix design procedure, since it was believed that strength of the concrete is an all pervading factor for all other desirable properties of concrete.

This paper throws light on durability of high strength self compacting concrete. It is believed that it is very much appropriate to discuss the strength and durability relationship, impact of water/cement ratio, permeability on durability of concrete.

\section{SELF COMPACTING CONCRETE (SCC)}

The exponential growth of population, rapid industrialization and increasing urbanization has tremendously enhanced the demand for infrastructure. In the process of creation of infrastructure the role of concrete has become very significant. Concrete was found to be one of the essential and indispensable materials to fulfill the need of construction industry. The flexibility, suitability and adoptability of the concrete have increased its utility at every stage of construction of structures. The strength and the durability of concrete depend up on the degree of compaction. The desirable workability may be achieved through vibration, but it is not possible to ensure full compaction. Hence inadequate compaction leads to the formation of large number of voids. The voids left in the concrete may reduce the strength and durability of concrete. The self compacting concrete has emerged as the panacea for this problem. Making concrete structures without vibration is not a new concept it has been existed in the past but the strength of those concretes were very low. The modern application of self compacting concrete (SCC) is focused on high strength, high performance and more reliable uniform quality. The contribution of researchers at the University of Tokyo, Japan led to the development of SCC that doesn't require vibration to achieve full compaction. Soon after its development it has become popular in Japan for prefabricated products and ready mix concrete. The successful use of SCC in Japan has drawn the attention of several European countries. They too have worked and formed a European federation (EFNARC) and gave design specifications, guidelines to produce and use high quality SCC.

The main characteristics of SCC are based on the properties of concrete in the fresh state. The main target of SCC mix design is on the ability to flow under its self weight without the need of vibration and its ability to flow through heavily congested 
reinforcement, its capability to retain homogeneity resisting segregation. The task of mix design is very crucial to produce the concrete that should essentially possess the following characteristics:

- Filling ability

- Passing ability

- Resistance against segregation.

The following test methods have been used to produce the concrete with above said workable conditions.

\subsection{V-Funnel Test}

The V-Funnel test is used to determine the filling ability of concrete. Initially the funnel is filled with about 12 liters of concrete without compacting or tamping simply by striking off and level the top of the concrete with trowel. Just within ten seconds open the trap door and allow the concrete to fall and time taken for complete discharge of concrete is noted. The entire test has been completed within 5 minutes.

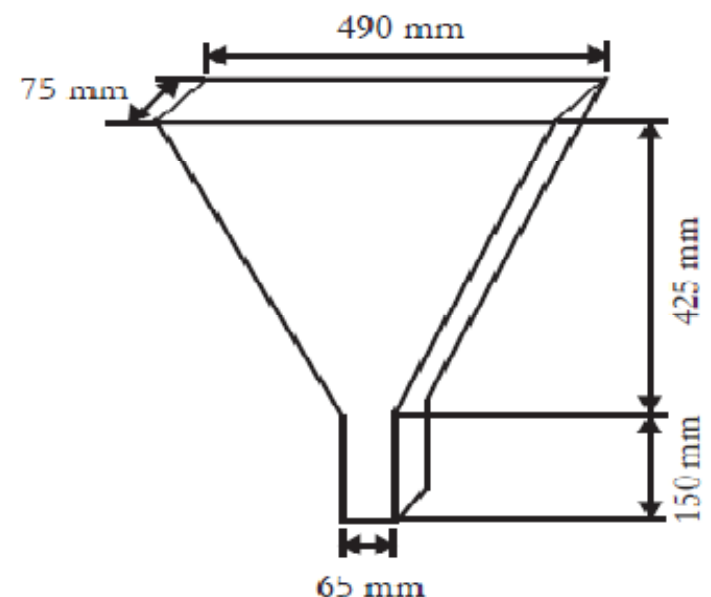

Fig.1. V-Funnel

\subsection{Slump Flow Test for Measuring Flowability}

The basic purpose of slump flow test is to know the horizontal free flow of SCC in absence of any obstructions. It was developed in Japan and used for the first time while underwater concrete is placed. The measure of the diameter of the concrete circle indicates filling and passing ability of the concrete. The basic equipment used in the test is almost similar to the equipment used in conventional slump test. The method of the test conduction is different from the traditional method, the sample concrete is placed in the mould when the slump cone is removed the sample collapses. The diameter of the spread of the concrete is measured, i.e. a horizontal distance is measured as against the vertical slump measured in the case of conventional test. While measuring the diameter of the spread the time that the sample takes to reach a diameter of
$500 \mathrm{~mm}$ (T50) is also measured. The test indicates the flowability of the SCC, the resistance and susceptibility of concrete to segregation. In fact the reliability on the test numerical data is not mere sufficient to judge the workability of concrete but it also requires previous experience and knowledge with SCC to conclude the state and condition of the concrete so as to suit the situation in field.

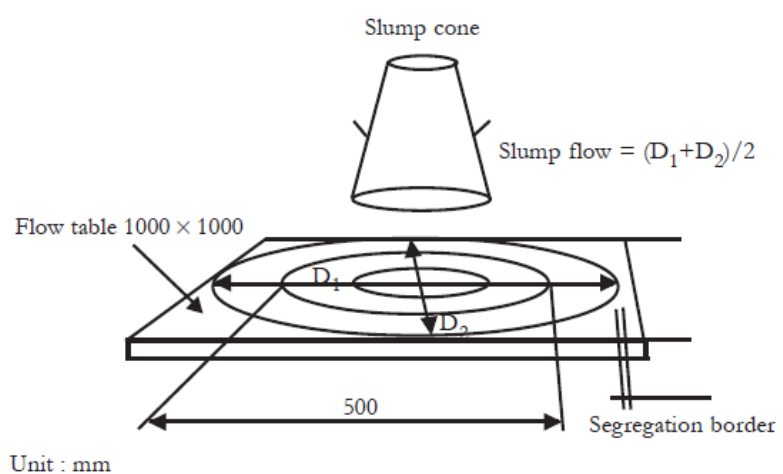

Fig.2 Flow Table

\subsection{L-Box Test}

The test is aimed to find out the passing ability of the concrete through the congested reinforcement. The test apparatus consists of a rectangular section of box in the form of ' $\mathrm{L}$ ' with both vertical and horizontal sections separated by movable gate, opposite to this vertical reinforcement bars are arranged. The vertical section is filled with concrete and then the gate is opened to allow the concrete to flow in to the horizontal section. When the flow has stopped the level of the concrete at the end of the horizontal section is taken as a proportion of that remaining in the vertical section. This shows the passing ability of concrete.

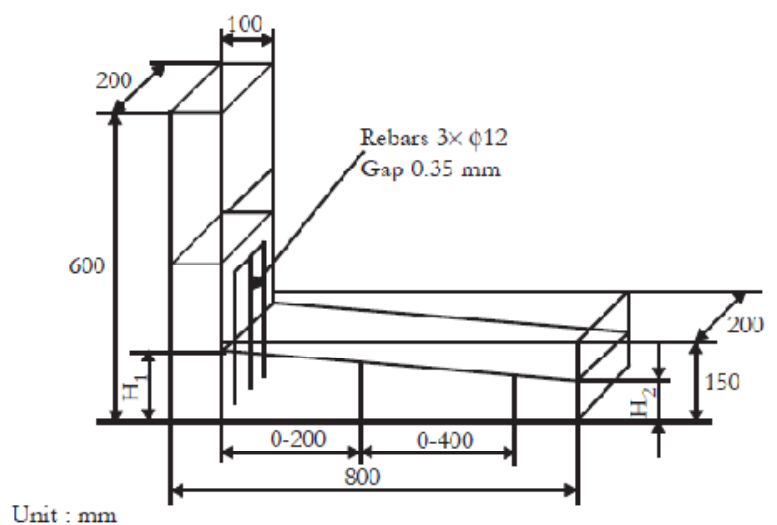

Fig.3 L-Box 


\section{IMPACT OF WATER/CEMENT RATIO ON DURABILITY OF CONCRETE}

The impact of water/cement ratio is very much significant on concrete. The increase in water quantity leads to the presence of more water this will become a contributory factor for volume change therefore higher water/cement ratio leads to higher permeability. The use of higher water /cement ratio leads to consecutive and cyclical disruptive actions. Higher water/cement ratio increases permeability, higher permeability causes volume change, volume change result in cracks, cracks causes disintegration of the structure eventually structure will be failed. Hence lower water/cement ratio is always needed to produce more durable, dense and impermeable concrete. The impact of water/cement ratio is greatly visible and identifiable in the micro-structures of the concrete. The effect of chloride ions on the concrete made of low water/cement ratio is very much slower than in the concrete with higher water/cement ratio. The reaction is $10-50$ times slower than that of higher water/cement ratio concrete. It has already been proved that low water/cement ratio concretes are less sensitive to carbonation affect, rather than higher water/cement ratio on concrete.

The effect of corrosion on steel reinforcement in low water/cement ratio concrete is greatly reduced or sometimes prevented.

In actual practice maintaining low water/cement ratio i.e. lower than 0.4 had been very difficult. The advent of modern super plasticizers had made it easy to produce the concrete even at 0.25 to 0.20 water/cement ratios. We could able to make a high strength and high performance self compacting concrete at 0.24 water/cement ratio.

Durability of the concrete may be understood as its ability to resist weathering, abrasion, chemical attack or any process of deterioration, if this concrete is said to be durable it has retain its original form, quality and serviceability when exposed to its working environment.

Out of all the factors influence the durability of concrete chemical attack is a chief factor which is responsible for deterioration of structures by causing volume change and cracking. When we study the chemical action on concrete we shall have to study sulphate attack, alkali - aggregate reaction, carbonation, acid attack and effect of sea water.

\section{INFLUENCE OF SULPHATE ATTACK ON CONCRETE}

Most of Soils contain sulphate residues in the form of Calcium, Sodium, Potassium and magnesium. Most of them are present either in soil or ground water. As the solubility of Calcium sulphate is low, ground water contains more quantities of other sulphates rather than calcium sulphates, the presence of Ammonium sulphate is predominant in agriculture soils and industrial effluents. Industrial structures exclusively concrete cooling towers are subjected to sulphate attack. Therefore the affect of sulphate on concrete structures is unavoidable. The intensity of sulphate attack is more severe when it attacks in solution form by entering the porous concrete and reacts with hydrated ccement products, rather than its affect in solid form. Magnesium sulphate causes more damage to concrete than other sulphates, sulphate attack may be evidenced in the form of whitish appearance. The sulphate attack may be evidenced when an increase in the volume of cement paste in concrete takes place during the chemical action between the product of hydration of cement and solution containing sulphates. In the hardened state of concrete $\mathrm{C}-\mathrm{A}-\mathrm{H}$ reacts with sulphate salt from outside calcium sulpho alluminate, as this product of the reaction responsible for increase of volume up to 227 percent, causes disintegration of concrete

The following equations represent the reactions of various sulphates with hardened cement paste; equation (1) shows how sodium sulphate is attacking

$\mathrm{Ca}(\mathrm{OH})_{2}, \mathrm{Ca}(\mathrm{OH})_{2}+\mathrm{Na}_{2} \mathrm{So}_{4} \cdot 10 \mathrm{H}_{2} \rightarrow \mathrm{CaSo}_{4} \cdot 2 \mathrm{H}_{2} \mathrm{O}+2 \mathrm{NaOH}$ $+8 \mathrm{H}_{2} \mathrm{O}$

Equation (2) shows the reaction of sodium sulphate with Calcium Aluminate Hydrate,

$2\left(3 \mathrm{CaO} \quad \mathrm{Al}_{2} \mathrm{O}_{3} \cdot 12 \quad \mathrm{H}_{2} \mathrm{O}\right)+3\left(\mathrm{Na}_{2} \mathrm{So}_{4} \cdot 10 \quad \mathrm{H}_{2} \mathrm{O}\right) \rightarrow$ $3 \mathrm{CaO} \cdot \mathrm{Al}_{2} \mathrm{O}_{3} \cdot 3 \mathrm{CaSo}_{4} \cdot 31 \mathrm{H}_{2} \mathrm{O}+2 \mathrm{Al}(\mathrm{OH})_{3}+6 \mathrm{NaOH}+17 \mathrm{H}_{2} \mathrm{O}$

In this reaction calcium Sulphate attacks only calcium alluminate and produce calcium Sulpho aluminate $\left(3 \mathrm{CaO} \cdot \mathrm{Al}_{2} \mathrm{O}_{3} \cdot 3 \mathrm{CaSo}_{4} \cdot 32 \mathrm{H}_{2} \mathrm{O}\right)$ known as attringite, the molecules of water may be 32 or 31 .

In fact the strength of the solution increases the rate of sulphate attack on concrete High water/cement ratio causes serious damage to concrete with in short duration of time. The concrete with low water/cement ratio reduces the intensity of damage by resisting the impact of magnesium sulphate.

\section{EXPERIMENTAL PROCEDURE}

The aim of the present study is to identify and estimate the effect of $\mathrm{H}_{2} \mathrm{SO}_{4}, \mathrm{HCL}$ and $\mathrm{Na}_{2} \mathrm{So}_{4}$ on concrete made up of micro silica, water proofer and super plasticizer. The workability studies are also conducted and the durability of the concrete is studied against the attack of $\mathrm{H}_{2} \mathrm{So}_{4}, \mathrm{HCL}$ and $\mathrm{Na}_{2} \mathrm{So}_{4}$. 


\subsection{Procedure for the Determination of Resistance of} Concrete to Sulphate Attack

The effect of sulphate attack on concrete and resistance of concrete to the attack has been tested in the laboratory, by immersing specimens of concrete cubes in the solution which contains $5 \%$ sodium sulphate. The effect of chemical attack has been estimated by taking change of mass in to consideration.

The test specimens of $10 \mathrm{X} 10 \mathrm{X} 10 \mathrm{~cm}$ cubes were immersed in $5 \%$ of Sodium sulphate solution over a period of time. The affect of sulphate attack on performance and properties of concrete are identified. In order to speed up the test, specimens are subjected to alternate cycles of immersion and drying. The resistance of concrete to the sulphate attack has been estimated by considering changes in their dynamic modules of elasticity. Even from the visual observation also the intensity of sulphate attack on cracking and the impact of disintegration is noticed.

\subsection{Test of Acid Attack on Concrete Specimens}

In fact concrete is not fully resistant to acids. All acids will have their impact on concrete. The rate of speed of action may be different but certainly they disintegrate concrete. Certain acids like Oxalic acid and Phosphoric acids do not have any effect on concrete they are totally harmless. All most all aggregates are susceptible to acid attack but siliceous aggregates are more resistant than calcareous aggregates. The contents like $\mathrm{Ca}(\mathrm{OH})_{2}$ and $\mathrm{C}-\mathrm{S}-\mathrm{H}$ gel are more susceptible to chemical attack. The liquids, whose $\mathrm{pH}$ value less than 5.5 and 4.5 cause serious damage to the concrete, such liquids speed up the disintegration process and ultimately destruct the structures. The intensity of corrosion caused by HCL at equal concentration is more in comparison with sulphuric acid. Since sulphuric acid forms a less soluble Calcium Sulphate on reaction with lime in concrete, the solution fills the gaps of concrete and prevents permeability and offers resistance to corrosion by acid. The present experimental study conducted on concrete specimens of size 10X10X10 cm. The specimens are immersed in $5 \% \mathrm{H}_{2} \mathrm{So}_{4}$, HCL and $\mathrm{Na}_{2} \mathrm{So}_{4}$ solutions respectively. The deterioration of the specimens is estimated by finding out the percentage reduction in weight of the specimen. The reduction in compressive strength of the specimens when they are immersed in chemical solutions is also identified.

\section{RESULTS}

Fresh Concrete properties of High Strength Self Compacting Concrete mix.
Table 1 The workability test values of SCC

\begin{tabular}{|c|c|}
\hline Grade & M80 \\
\hline w/c $\mathbf{c}_{\mathbf{m}}$ & 0.23 \\
\hline Slump flow(mm) & 661.41 \\
\hline T50 (sec) & 5.00 \\
\hline V-funnel (sec) & 12.00 \\
\hline V-funnel T5min(sec) & 13.00 \\
\hline L-Box (h2/h1) & 0.9 \\
\hline
\end{tabular}

Table 2 Average weight of specimens of size $10 X 10 X 10 \mathrm{~cm}$ at 28 days without chemical immersion of High Strength Self compacting Concrete of M80 grade

\begin{tabular}{|c|c|c|}
\hline & Grade & $\begin{array}{l}\text { Average } \\
\text { without } \\
\text { Immersion }\end{array}$ \\
\hline 1 & M80 & \multicolumn{1}{|c|}{ cheight } \\
\hline 2 & M80 & 2.13 \\
\hline 3 & M80 & 2.13 \\
\hline
\end{tabular}

Table 3 percentage decrease of weight specimen $(100 \mathrm{~mm} \mathrm{x}$ $100 \mathrm{~mm} \times 100 \mathrm{~mm})$ at 28 days with different chemical immersion of High Strength Self Compacting Concrete of M80 grade

\begin{tabular}{|c|c|c|c|}
\hline & Grade & $\begin{array}{c}\text { Name of the } \\
\text { Chemical used (8\%) }\end{array}$ & $\begin{array}{c}\text { Average weight } \\
\text { with chemical } \\
\text { Immersion }\end{array}$ \\
\hline 1 & M80 & Hydrochloric Acid & 1.89 \\
\hline 2 & M80 & Sulphuric Acid & 1.81 \\
\hline 3 & M80 & Sodium Sulphate & 1.9 \\
\hline
\end{tabular}

Table 4 Percentage decrease of weight after chemical immersion

\begin{tabular}{|c|c|c|c|c|}
\hline Grade & $\begin{array}{l}\text { Average } \\
\text { weight } \\
\text { without } \\
\text { chemical } \\
\text { Immersi } \\
\text { on (Kg) }\end{array}$ & $\begin{array}{l}\text { Name of } \\
\text { the } \\
\text { Chemical } \\
\text { used (8\%) }\end{array}$ & $\begin{array}{l}\text { Decrease } \\
\text { weight } \\
\text { after 28 } \\
\text { day } \\
\text { chemical } \\
\text { immersio } \\
\mathrm{n}(\mathrm{Kg})\end{array}$ & $\begin{array}{l}\text { percentage } \\
\text { decrease in } \\
\text { weight } \\
\text { after 28 } \\
\text { days }\end{array}$ \\
\hline M80 & 2.13 & $\begin{array}{l}\text { Hydrochlo } \\
\text { ric Acid }\end{array}$ & 1.89 & 11.26 \\
\hline M80 & 2.12 & $\begin{array}{l}\text { Sulphuric } \\
\text { Acid }\end{array}$ & 1.81 & 14.62 \\
\hline M80 & 2.13 & $\begin{array}{l}\text { Sodium } \\
\text { Sulphate }\end{array}$ & 1.91 & 10.32 \\
\hline
\end{tabular}




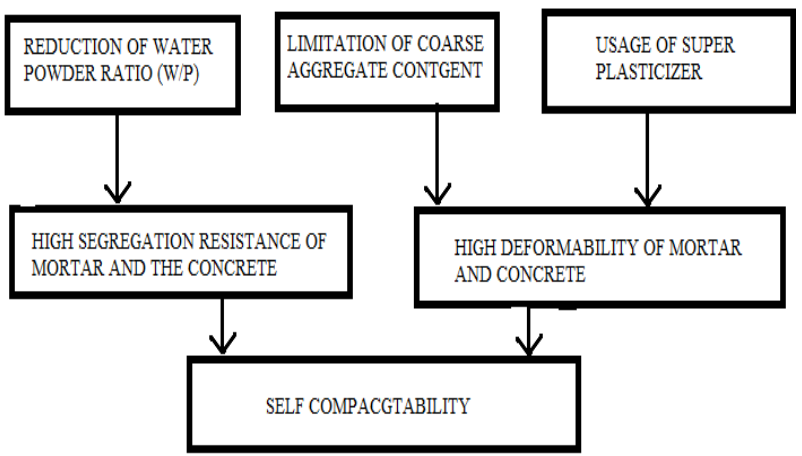

Fig.4 Flow chart represents making of Self -Compacting Concrete

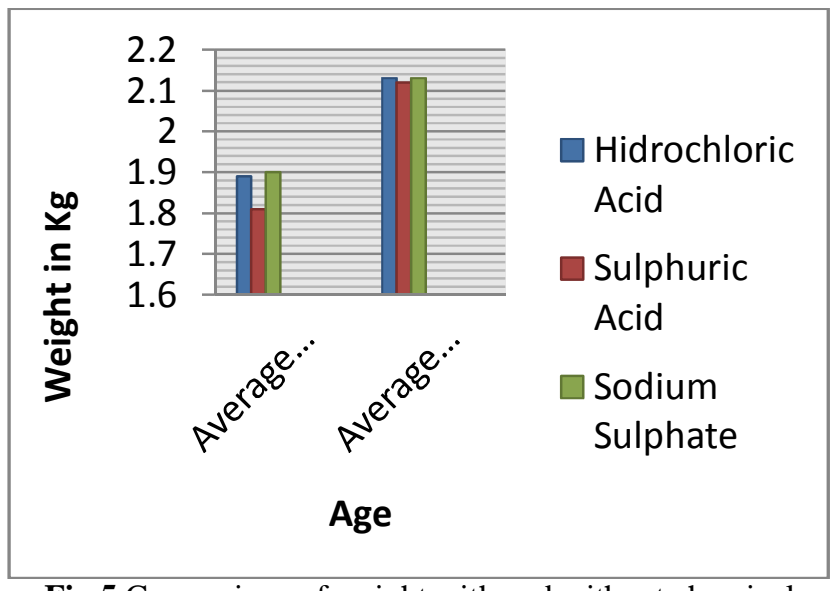

Fig.5 Comparison of weight with and without chemical immersion

Table 5 Percentage decrease in compressive strength of specimen at 28 days without \& with different chemical immersion of High Strength Self Compacting Concrete

\begin{tabular}{|c|l|l|l|l|}
\hline & $\begin{array}{l}\text { Compressiv } \\
\text { e strength } \\
\text { without } \\
\text { chemical } \\
\text { immersion }\end{array}$ & $\begin{array}{l}\text { Chemic } \\
\text { al used } \\
(5 \%)\end{array}$ & $\begin{array}{l}\text { Decrease in } \\
\text { Compressi } \\
\text { ve strength } \\
\text { after 28 } \\
\text { day } \\
\text { chemical } \\
\text { immersion }\end{array}$ & $\begin{array}{l}\text { percentag } \\
\text { decrease } \\
\text { in } \\
\text { compressi } \\
\text { ve } \\
\text { strength } \\
\text { after 28 } \\
\text { days }\end{array}$ \\
\hline M80 & $82 \mathrm{~N} / \mathrm{mm}^{2}$ & $\mathrm{HCL}$ & $\begin{array}{c}68.62 \\
\mathrm{~N} / \mathrm{mm}^{2}\end{array}$ & 16.31 \\
\hline M80 & $82 \mathrm{~N} / \mathrm{mm}^{2}$ & $\mathrm{H}_{2} \mathrm{SO}_{4}$ & $\begin{array}{c}43.40 \\
\mathrm{~N} / \mathrm{mm}^{3}\end{array}$ & 47.07 \\
\hline M80 & $82 \mathrm{~N} / \mathrm{mm}^{2}$ & $\mathrm{Na}_{2} \mathrm{SO}_{4}$ & $\begin{array}{c}65.71 \\
\mathrm{~N} / \mathrm{mm}^{4}\end{array}$ & 19.86 \\
\hline
\end{tabular}

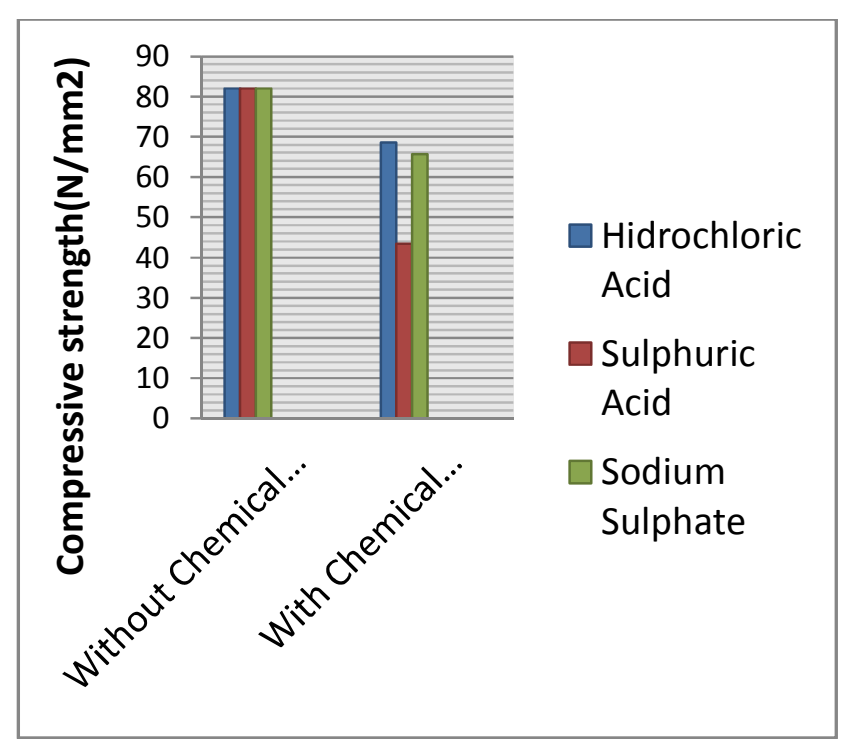

Fig.6 Reduction of Compressive strength before and after chemical immersion

Table 6 Summary of common testing methods and limiting test values for SCC

\begin{tabular}{|c|c|c|c|}
\hline $\begin{array}{l}\text { Property } \\
\text { measured }\end{array}$ & $\begin{array}{l}\text { Test } \\
\text { method }\end{array}$ & Material & $\begin{array}{l}\text { Recommended } \\
\text { values }\end{array}$ \\
\hline \multirow{4}{*}{$\begin{array}{c}\text { Flowabili } \\
\text { ty / } \\
\text { Filling } \\
\text { ability }\end{array}$} & $\begin{array}{c}\text { Recommen } \\
\text { ded values }\end{array}$ & Concrete & $\begin{array}{c}650-800 \mathrm{~mm} \\
\text { Average flow } \\
\text { diameter }\end{array}$ \\
\hline & $\mathrm{T}_{50}$ & Concrete & $\begin{array}{c}2-5 \mathrm{sec} \\
\text { Time to flow } \\
500 \mathrm{~mm}\end{array}$ \\
\hline & V - funnel & $\begin{array}{l}\text { Concrete } \\
\text { / mortar }\end{array}$ & $\begin{array}{c}6-12 \mathrm{sec} \\
\text { Time for } \\
\text { emptying of } \\
\text { funnel } \\
\end{array}$ \\
\hline & Orimet & Mortar & $\begin{array}{c}0-5 \mathrm{sec} \\
\text { Time for } \\
\text { emptying of } \\
\text { apparatus }\end{array}$ \\
\hline \multirow{3}{*}{$\begin{array}{l}\text { Passing } \\
\text { ability }\end{array}$} & $\mathrm{U}-\mathrm{box}$ & Concrete & $\begin{array}{c}0-30 \mathrm{~mm} \\
\text { Difference in } \\
\text { heights in two } \\
\text { limbs }\end{array}$ \\
\hline & $\mathrm{L}-$ box & Concrete & $\begin{array}{l}\text { } 0.8-1.0 \\
\text { Ratio of heights } \\
\text { at beginning } \\
\text { and end of flow }\end{array}$ \\
\hline & $\mathrm{J}$ - ring & Concrete & $\begin{array}{l}0-10 \mathrm{~mm} \\
\text { Difference in } \\
\text { heights at the } \\
\text { beginning and } \\
\text { end of flow }\end{array}$ \\
\hline
\end{tabular}




\begin{tabular}{|c|c|c|c|}
\hline \multirow{3}{*}{$\begin{array}{l}\text { Segregati } \\
\text { on } \\
\text { potential }\end{array}$} & $\begin{array}{l}\text { Settlement } \\
\text { column test }\end{array}$ & Concrete & $\begin{array}{c}>0.95 \\
\text { Segregation } \\
\text { ratio }\end{array}$ \\
\hline & $\begin{array}{c}\text { Sieve } \\
\text { stability } \\
\text { test }\end{array}$ & Concrete & $\begin{array}{c}5-15 \% \text { sample } \\
\text { passing through } \\
5 \mathrm{~mm} \text { sieve }\end{array}$ \\
\hline & $\begin{array}{c}\text { Penetration } \\
\text { test }\end{array}$ & Concrete & $\begin{array}{c}\text { Penetration } \\
\text { depth }<8 \mathrm{~mm}\end{array}$ \\
\hline
\end{tabular}

\section{FUTURE SCOPE AND ADVANTAGES OF SCC}

Since from the development of SCC in Japan in the late 1980s, the research, development and use of SCC has spread all over the world. Approximately up to $5 \%$ of the Swedish ready-mix market depends on SCC and the research is still being continued in Europe. Significant amount of research and development works are being conducted in Canada and USA. The first North American conference was held in November 2002 by North Western University. American Concrete organizations such as ACI, ASTM and PCI have all recently formed committees to formulate guidelines, standards and specifications for SCC. The usage of SCC in precast applications is getting increased day by day in North America. Some of the countries like New Zealand, Australia, Argentina and some of Gulf countries have already started research and development work on SCC. A third international symposium on SCC was held in Iceland in 2003 where by many research papers were presented for further future development of SCC.

The use of SCC was found to offer economic, social and environmental benefits over traditional vibrated concrete constructions. More particularly SCC has provided a solution to address many environmental issues like,

i. Noise reduction in the place of manufacturing as well as at the place of applications, i.e. on site.

ii. It also prevents personal injuries from noise and manual handling.

iii. It reduces the consumption of electricity.

iv. It reduces overall maintenance cost.

v. It saves the cost incurred for vibration equipment.

vi. It has been immensely used in precast and pre stressed fibre concrete.

\section{CONCLUSIONS}

Percentage decrease in weights of the specimens without and with immersion in $\mathrm{HCL}, \mathrm{H}_{2} \mathrm{So}_{4}$ and $\mathrm{Na}_{2} \mathrm{So}_{4}$ solutions of $5 \%$ concentration at 28 days was found to be $11.26,14.62$ and $10.32 \%$ respectively. From these results it has been identified that the intensity of attack by $\mathrm{H}_{2} \mathrm{SO}_{4}$ is comparatively more than the attack of $\mathrm{HCL}$ and $\mathrm{Na}_{2} \mathrm{SO}_{4}$ on the specimens. The percentage decrease in compressive strength of the specimens without and with immersion in $\mathrm{HCL}, \mathrm{H}_{2} \mathrm{SO}_{4}$ and $\mathrm{Na}_{2} \mathrm{SO}_{4}$ solution of $5 \%$ concentration after 28 days was found to be $16.31,47.07$ and $19.86 \%$ respectively. It is noticed that the intensity of attack by $\mathrm{H}_{2} \mathrm{So}_{4}$ is comparatively more than the attack of $\mathrm{HCL}$ and $\mathrm{Na}_{2} \mathrm{So}_{4}$ on the specimens. The reduction of strength due to the affect of $\mathrm{H}_{2} \mathrm{So}_{4}$ on the concrete is more significant

\section{REFERENCES}

[1] Okamura H., Ozawa K. and Ouchi M. (2000), Selfcompacting concrete. Structural Concrete, 1, No.1, Mar., 3-17.

[2] Dr. R. Sri Ravindrarajaiah, D. Siladyi and B. Adamopoulos "Development of high strength self compacting concrete with reduced segregation potential, "Proceedings of the 3rd International RILEM Symposium, Reykjavik, Iceland, 17-20 August 2003.

[3] Tanigawa Y., Mori H., Yonezawa T., Izumi I. and Mitsui K.. (1989/1990), Evaluation of the flowability of high-strength concrete by L-flow test. Proceedings of the Annual Conference of the Architectural Institute of Japan.

[4] Ozawa K., Maekawa K. and Okamura H. (1990)High performance concrete with high filling ability. Proceedings of the RILEM Symposium, Admixtures for Concrete, Barcelona.

[5] Tangtermsirikul S., Sakamoto J., Shindoh T. and Matsuoka Y. (1991), Evaluation of resistance to segregation of super workable concrete and the role of a new type of viscosity agent. Reports of the Technical Research Institution Taise Corporation, Japan, No. 24, pp. 369-376.

[6] Nilsson M. (1998), Project on Self-compacting Bridge Concrete. Swedish National Road Administration (SNRA), Publication 1998:71 E, ISSN 1401-9612, p. 19.

[7] Sakamoto J., Matsuoka Y., Shindoh T. and Tangtermsirikul S. (2000), Application of super workable concrete to actual construction. Proceedings of Concrete, Conference, University of Dundee.

[8] Kuroiwa S., Matsuoka Y., Hayakawa M. and Shindoh T. (1993), Application of Super Workable Concrete to Construction of a 20-storey Building. ACI, SP-140.

[9] M.S.Shetty (2013), Concrete Technology, theory and Practice, S.Chand \& Company,New Delhi.

[10] Ouchi M. and Ozawa K. (eds). (1998), Proceedings of the International Workshop on Self-Compacting Concrete, Kochi, Japan Society of Civil Engineers, ISBN 4-8106-0310-5.

[11] Uomoto T. and Ozawa K. (eds). (1999), Recommendation for SCC. JSCE Concrete Engineering, Series 31, Tokyo, Japan.

[12] Domone P. L. and Chai H. W. (1996), Design and testing of SCC: Production methods and workability of concrete. Proceedings of an International RILEM Conference. E \& F N Spon, London, ISBN 41922070 4.

[13] Petersson O. and Billberg P. (1996), A model for SCC: Production methods and workability of concrete. 
International RILEM Conference. E \& F N Spon, London, ISBN 419220704.

[14] Skarendahl A. and Petersson O. (eds). (1999), Proceedings of the 1st International RILEM Symposium on SCC. RILEM Publications, p. 786, ISBN 2-912143-09-8. RILEM. TC CSC: Casting of SCC, www.rilem.ens-cachan.fr/csc.

[15] European Federation of Producers And Contractors Of Specialist Products For Structures (EFNARC) (2002), Specifications and Guidelines for Self-Compacting Concrete. EFNARC, Surrey, Also available on the internet at: www.efnarc.org.

\section{BIOGRAPHIES}

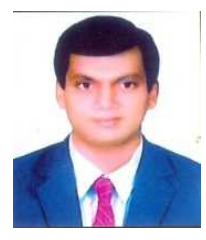

N. Venkat Rao holds Master's Degree in Structural Engineering From JNTU Hyderabad and currently working as an Associate Professor in the Department of Civil Engineering at Vardhaman College of Engineering (Autonomuos).

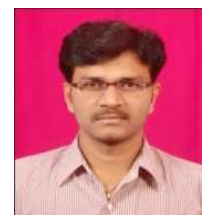

M. Rajasekhar received the degree Master of technology in Environmental Engineering from JNTU Hyderabad. He has published research papers on waste water treatment and concretes.

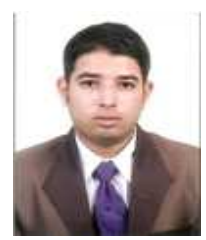

Mohd Mujjebuddin Ahmed received his master's degree in Structures from JNTU Hyderabad. Presently working as an Assistant Professor in the Department of Civil Engineering at Vardhaman College of Engineering (Autonomous) 